\title{
Cognition and quality of life relationship among the elderly community: a cross-sectional study
}

\author{
Relação da cognição e qualidade de vida entre idosos comunitários: estudo transversal
}

Relación de cognición y calidad de vida en la comunidad mayor: estudio de estudio transversal

Barbara Maria Lopes da Silva Brandão' ORCID: 0000-0002-6652-9615

Alice Maria Barbosa da Silva' ORCID: 0000-0001-7700-709X Rafaella Queiroga Souto" ORCID: 0000-0002-7368-8497

Fabia Alexandra Pottes Alves' ORCID: 0000-0002-2478-5346

Gleicy Karine Nascimento de Araújo" ORCID: 0000-0002-4395-6518

Viviane Cristina Fonseca da Silva Jardim' ORCID: 0000-0003-2529-7579

Hulda Vale de Araújo' ORCID: 0000-0002-0474-7158

'Universidade Federal de Pernambuco. Recife, Pernambuco, Brazil. "Universidade Federal da Paraíba. João Pessoa, Paraíba, Brazil.

How to cite this article: Brandão BMLS, Silva AMB, Souto RQ, Alves FAP, Araújo GKN, Jardim VCFS, et al. Cognition and quality of life relationship among the elderly community: a cross-sectional study. Rev Bras Enferm. 2020;73(Suppl 3): e20190030. doi: http://dx.doi.org/10.1590/0034-7167-2019-0030

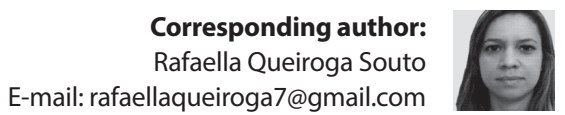

EDITOR IN CHIEF: Dulce Barbosa ASSOCIATE EDITOR: Hugo Fernandes

\section{ABSTRACT}

Objective: to assess cognitive functions and their association with quality of life among elderly people enrolled in a Family Health Unit (FHU) of Primary Health Care in Recife-PE. Methods: a quantitative, descriptive, cross-sectional study in which elderly aged 60 years and over were studied. Results: $76.7 \%$ of the elderly were women and the age group was less than or equal to 70 years. $68.6 \%$ had cognitive impairment, and in the quality of life assessment it was found that the social participation facet had the highest mean score among the elderly (14.25), while the lowest was observed in the sensory functioning facet (9.10). There was an association between cognitive decline and quality of life. Conclusion: most of the elderly had good quality of life rates, but low cognitive level. Using screening tools allows early detection of health problems, guiding the nursing staff in the construction of preventive measures.

Descriptors: Aged; Cognition; Quality of Life; Primary Health Care; Public Health.

\section{RESUMO}

Objetivo: avaliar as funções cognitivas e sua associação com a qualidade de vida entre idosos cadastrados em uma Unidade de Saúde da Família (USF) da Atenção Primária à Saúde da cidade do Recife-PE. Métodos: pesquisa quantitativa, descritiva, transversal, na qual foram estudados idosos com idade igual ou superior a 60 anos. Resultados: $76,7 \%$ dos idosos eram mulheres e faixa etária era menor ou igual a 70 anos. $68,6 \%$ possuíam déficit cognitivo, e na avaliação da qualidade de vida verificou-se que a faceta participação social apresentou o maior escore médio entre os idosos $(14,25)$, enquanto que o menor foi observado na faceta funcionamento do sensório $(9,10)$. Houve associação entre declínio cognitivo e qualidade de vida. Conclusão: a maioria dos idosos apresentou bons índices de qualidade de vida, porém, baixo nível cognitivo. Utilizar instrumentos de rastreio permite detectar precocemente problemas de saúde, norteando a equipe de enfermagem na construção de medidas preventivas.

Descritores: Idoso; Cognição; Qualidade de Vida; Atenção Primária à Saúde; Saúde Pública.

\section{RESUMEN}

Objetivo: para evaluar las funciones cognitivas y su asociación con la calidad de vida de las personas de edad avanzada inscritas en una Unidad de Salud Familiar (USF) de Atención Primaria de Salud en Recife-PE. Métodos: estudio cuantitativo, descriptivo, transversal, en el que se estudiaron ancianos de 60 años y más. Resultados: El 76,7\% de los ancianos eran mujeres y el grupo de edad era menor o igual a 70 años. El 68,6\% tenía deterioro cognitivo, y en la evaluación de la calidad de vida se encontró que la faceta de participación social tenía la puntuación media más alta entre los ancianos $(14,25)$, mientras que la faceta de funcionamiento sensorial fue la más baja $(9,10)$. Hubo una asociación entre el deterioro cognitivo y la calidad de vida. Conclusión: la mayoría de los ancianos presentaron índices de buena calidad de vida, pero de bajo nivel cognitivo. El uso de instrumentos de detección permite la detección temprana de problemas de salud, guiando al personal de enfermería en la construcción de medidas preventivas.

Descriptores: Anciano; Cognición; Calidad de Vida; Atención Primaria de Salud; Salud Pública. 


\section{INTRODUCTION}

Population aging translates as a dynamic and progressive phenomenon, which is intrinsically associated with the increased prevalence of Chronic Noncommunicable Diseases (CNCDs) (1). These diseases are characterized by slow progress, multiple etiology and long duration, especially cardiovascular diseases, cancer, respiratory diseases, hypertension and diabetes mellitus, which advance with age and have a financial impact on health systems. In addition, they directly affect the quality of life and cognitive ability of the elderly, such as Type 2 Diabetes Mellitus and its relationship with the evolution of more severe forms of cognitive impairment ${ }^{(2-3)}$.

It is estimated that in 2070 the elderly Brazilian population will reach a percentage above $35 \%$, surpassing the indexes of developed countries. With the increase in life expectancy, there is a need for actions to promote quality of life and reduce disabilities in these individuals ${ }^{(4)}$. Quality of life can be defined as an individual perception, based on criteria of personal satisfaction and collective well-being, that relates to the goals, expectations, standards and concerns in the living environment ${ }^{(5-6)}$. Thus, since, in old age, quality of life comprises aspects such as health, living conditions, work, social relations and autonomy, its evaluation is indispensable to the process of caring for the elderly and should be included in actions of health services ${ }^{(5-7)}$.

With regard to markers for successful, quality-of-life aging, cognitive function is an important integral. Successful aging represents a subjective and positive perspective, facing individuality and sociocultural differences, with satisfactory functioning and without disabilities ${ }^{(8)}$. This process can be achieved by promoting the physical, mental and social well-being of the elderly, encouraging social inclusion and participation ${ }^{(9)}$.

Therefore, changes in cognitive functions are considered normal with the aging process through the gradual biological loss of reasoning, perception and memory skills ${ }^{(10)}$. However, when cognitive decline impairs the independence of the elderly and their personal and social relationships, this contributes to the decrease of self-care and autonomy, leading to feelings of insecurity, low self-esteem and social isolation and, consequently, decline in quality of life of these individuals $s^{(11-12)}$.

Among the factors that influence the cognitive profile of the elderly, studies indicate that education, age, gender, socioeconomic and psychological profile, and marital status reproduce significant differences in cognitive performance ${ }^{(13)}$. However, while some of these influences are connected with the environment, health inequalities pose a challenge for the elderly to establish an adequate and dignified quality of life, compatible with their rights $^{(14)}$.

Although public policies ensure the social rights of the elderly and propose conditions to promote their autonomy, integration and effective participation in society, as well as the right to health, implementation of these policies still fails to promote successful aging, as it requires a change in health care that prioritizes prevention measures against the treatment of already established health problems ${ }^{(15)}$.

Thus, since evaluation studies between cognitive functions and quality of life are limited, it is believed that conducting research on this socially relevant topic contributes to the expansion of research in the area. Hence, it would enable the development of effective policies and actions to contribute to the planning of health care, care and treatment for this population, aiming at the promotion of a healthy life, disease prevention, improving the management of public resources ${ }^{(16)}$.

\section{OBJECTIVE}

To assess cognitive functions and their association with quality of life among elderly people enrolled in a Family Health Unit (FHU) of Primary Health Care in the city of Recife, Pernambuco State.

\section{METHODS}

\section{Ethical aspects}

The research is a clipping of the research project approved by the Research Ethics Committee Involving Human Beings of Universidade Federal de Pernambuco (REC-UFPE). It respected the national regulation on research involving human being $s^{(17)}$.

\section{Design, place of study and period}

This is a quantitative, descriptive, cross-sectional research, guided by the STROBE tool. Performed at a FHU located in Microarea III of the Health District IV in the city of Recife. Data collection was performed from August 2016 to April 2017.

The criterion for choosing this place was its proximity to Universidade Federal de Pernambuco (UFPE), allowing to act in the social responsibility of the university with its surroundings.

\section{Sample; inclusion and exclusion criteria}

The sample consisted of 159 elderlies (calculated using the formula for finite population epidemiological studies), elected by systematic and proportional sampling in relation to the three family health teams of the unit mentioned above. Inclusion criteria were: persons aged 60 years and over, who understood the information contained in the Informed Consent Form about the purpose of the research and resided permanently in the registered domicile.

\section{Study protocol}

Data collection was performed through tools for multidimensional evaluation of the elderly, personal identification tools and sociodemographic conditions designed through the Brazil Old Age Schedule (BOAS) ${ }^{(18)}$, Mini-Mental State Exam (MMSE) ${ }^{(19-2)}$ and the World Health Organization Quality of Life (WHOQOL-OLD) ${ }^{(21)}$. The collection procedure took place at the elderly's own residence, in which each pair of interviewers was followed by a Community Health Agent. The elderly who accepted to participate in the research were read the Free and Informed Consent Form (ICF) and, later, their signature and application of tools. Questions and answers were read to the elderly, and the interviewers waited for him to point out the alternative that suited him best. The interview mean time was one and a half hours. 
Prior to the start of data collection, students and teachers were trained during two training sessions for the use of data collection tools. The collection team consisted of approximately 30 students from different courses and, among these, four were responsible for entering the database and organizing the weekly collection scales, in the morning and afternoon shifts.

The BOAS questionnaire is a functional and multidimensional tool that involves several areas of the elderly's life, including physical and mental aspects, daily activities and socioeconomic situation. It is divided into nine sections, however, for this study, only a few variables were selected (gender, age, education, marital status, income and retirement) ${ }^{(18)}$. This cut was made from the verification that only these questions would be sufficient to reach the objective proposed in this manuscript.

The second questionnaire used was the MMSE, which is a brief test with 30 items, with quick application, which investigates the impairment of cognitive functions. The tool covers seven categories of specific functions such as: space/time orientation, attention, short-term memory, calculus, language, recording and visual constructive capacity ${ }^{(19-20)}$. This tool was chosen because it is used in several countries and by renowned researchers, allowing to assess the cognitive deficit of elderly participants.

The WHOQOL-OLD, a validated tool for assessing quality of life in the elderly, was developed by the World Health Organization. It consists of 24 questions divided into six domains: Sensory Functioning (SF), Autonomy (AUT), Past, Present and Future Activities (PPF), Social Participation (SOP), Death and Dying (DAD), and Intimacy (INT). Each domain contains four questions, and the answers follow a scale from 1 to 5 , representing a positive scale, that is, the higher the score, the better the quality of life ${ }^{(21)}$. The WHOQOL-OLD was chosen because it is a widely applied tool, used internationally and specific to the age group assessed in the study.

Cognitive deficit was determined as the dependent variable of the study, while the independent variables were sociodemographic variables (gender, age, education, marital status, housing arrangement) and quality of life.

\section{Analysis of results, and statistics}

Prior to typing, protocols were checked and corrected by a data collection supervisor. Data were entered and analyzed in SPSS version 21.0 using descriptive statistics (absolute, relative, mean, Standard Deviation, minimum and maximum) and inferential statistics (Pearson's Chi-Square Test, Fisher's Exact Test and the Adjusted Multiple Regression Model).

The entry criteria of the variables in the multiple logistic regression model was set at $p<0.02$, based on the result of the bivariate analysis. In the end, the value of 0.05 or less was considered significant.

\section{RESULTS}

The elderly in the study were, in their largest proportion, female $(76.7 \%)$, being in the age group less than or equal to 70 years (54.1\%). 34\% were married/live together, $71.1 \%$ had an income of up to one minimum wage and $66.7 \%$ supported their retirement. Regarding education, $66.7 \%$ were literate and $44.7 \%$ attended primary school.
Regarding MMSE, the attention/calculation domain showed lower score (1.24 \pm 1.33$)$. On the other hand, the orientation domain presented the highest score $(8.65 \pm 1.92)$. In addition, $68.6 \%$ of the elderly presented poor cognitive performance in this tool.

Regarding the bivariate analysis of sociodemographic variables and quality of life with MMSE, a significant statistical association was observed in education, marital status and quality of life (Table 1). Cognitive deficit predominated in women over 70 years old, illiterate, single, living alone, over 1 wage and with poor quality of life.

Table 1 - Association between sociodemographic variables, quality of life and cognitive impairment among participating individuals, Recife, Pernambuco, Brazil, 2016-2017, N=159

\begin{tabular}{|c|c|c|c|}
\hline \multirow[b]{2}{*}{ Variables } & \multicolumn{2}{|c|}{ MMSE } & \multirow[b]{2}{*}{$\underset{\text { value }^{*}}{p}$} \\
\hline & $\begin{array}{c}\text { With } \\
\text { deficit } \\
\text { n (\%) }\end{array}$ & $\begin{array}{c}\text { Without } \\
\text { deficit } \\
\text { n (\%) }\end{array}$ & \\
\hline \multicolumn{4}{|l|}{ Gender } \\
\hline Male & $11(29.7)$ & $26(70.3)$ & \multirow{2}{*}{0.79} \\
\hline Female & $39(32.0)$ & $83(68.0)$ & \\
\hline \multicolumn{4}{|l|}{ Age } \\
\hline$\leq 70$ years & $27(31.4)$ & $59(68.6)$ & \multirow{2}{*}{0.98} \\
\hline$>70$ years & $23(31.5)$ & $50(68.5)$ & \\
\hline \multicolumn{4}{|l|}{ Schooling } \\
\hline Literate & $30(28.3)$ & $76(71.7)$ & \multirow{2}{*}{0.22} \\
\hline Iliterate & $20(37.7)$ & $33(62.3)$ & \\
\hline \multicolumn{4}{|l|}{ Marital status } \\
\hline Married/living together & $38(74.5)$ & $13(25.5)$ & \multirow[t]{2}{*}{0.001} \\
\hline Widower/divorced/never married & $35(79.5)$ & $9(20.5)$ & \\
\hline \multicolumn{4}{|l|}{ Housing arrangement } \\
\hline Live alone & $12(54.5)$ & $10(45.5)$ & \multirow[t]{2}{*}{0.01} \\
\hline Live with someone & $38(27.7)$ & $99(72.3)$ & \\
\hline \multicolumn{4}{|l|}{ Income } \\
\hline Up to 1 wage & $35(31.0)$ & $78(69.0)$ & \multirow[t]{2}{*}{0.840} \\
\hline Over 1 & $15(32.6)$ & $31(67.4)$ & \\
\hline \multicolumn{4}{|l|}{ Quality of life } \\
\hline Low & $14(58.3)$ & $10(41.7)$ & \\
\hline Medium/high & $34(25.8)$ & $98(74.2)$ & 0.001 \\
\hline
\end{tabular}

Table 2 shows the Multiple Logistic Regression Model of cognitive deficit. Only variables that presented $p<0.02$ in the bivariate analyzes (marital status, housing arrangement and quality of life) were included in the model. The data allow inferring that widowed, divorced and never married individuals have 3.87 times the chance of presenting cognitive deficit. Moreover, the elderly with poor quality of life have 3.41 times the chance of having this deficit.

Table 2 - Variables associated with cognitive impairment using adjusted logistic regression, Recife, Pernambuco, Brazil, 2016-2017

\begin{tabular}{lccc}
\hline Variables & OR & CI & $\begin{array}{c}\boldsymbol{p} \\
\text { value* }\end{array}$ \\
\hline $\begin{array}{l}\text { Marital status } \\
\quad \text { Married/iving together }\end{array}$ & 1.00 & - & - \\
$\quad$ Widower/divorced/never married & 3.87 & {$[1.57-9.56]$} & 0.003 \\
$\begin{array}{l}\text { WHOQOL } \\
\quad \text { Low quality of life }\end{array}$ & 3.41 & {$[1.34-8.64]$} & 0.010 \\
$\quad$ Medium/high quality of life & 1.00 & - & - \\
\hline Adjusted $R^{2} \cdot 0.166$ & & &
\end{tabular}

Note: WHOQOL: World Health Organization Quality of Life; OR = Odds Ratio; $\mathrm{Cl}=$ confidence interval; *Test significance. 
Table 3 - Reliability of Mini-Mental State Exam Items. Recife, Pernambuco, Brazil, 2016-2017

\begin{tabular}{|c|c|c|c|}
\hline & $\begin{array}{c}\text { Scale mean } \\
\text { without item }\end{array}$ & $\begin{array}{l}\text { Scale variable } \\
\text { without item }\end{array}$ & a \\
\hline What day is it today? & 20.50 & 19.85 & 0.83 \\
\hline What month are we in? & 20.33 & 20.31 & 0.83 \\
\hline What year is it? & 20.50 & 19.22 & 0.83 \\
\hline What day of the week is it? & 20.36 & 20.57 & 0.84 \\
\hline What time is it about? & 20.42 & 20.87 & 0.84 \\
\hline Where are we at? & 20.26 & 21.30 & 0.84 \\
\hline What is this place here? & 20.28 & 20.95 & 0.83 \\
\hline $\begin{array}{l}\text { What neighborhood are we in or what's } \\
\text { the name of a nearby street? }\end{array}$ & 20.27 & 21.21 & 0.83 \\
\hline What city are we in? & 20.35 & 20.49 & 0.83 \\
\hline What state are we in? & 20.35 & 20.49 & 0.83 \\
\hline Interviewee repeat the word car & 20.35 & 20.79 & 0.84 \\
\hline Interviewee repeating the word vase & 20.38 & 20.74 & 0.84 \\
\hline Interviewee repeating the word brick & 20.30 & 21.13 & 0.84 \\
\hline The value of $100-7$ & 20.68 & 19.53 & 0.83 \\
\hline The value of $93-7$ & 21.06 & 20.49 & 0.84 \\
\hline The value of $86-7$ & 21.00 & 20.21 & 0.84 \\
\hline The value of $79-7$ & 20.93 & 19.97 & 0.83 \\
\hline Interviewee repeating the word car & 20.60 & 20.10 & 0.84 \\
\hline Interviewee repeating the word vase & 20.79 & 20.17 & 0.84 \\
\hline Interviewee repeat the word brick & 20.62 & 20.56 & 0.84 \\
\hline $\begin{array}{l}\text { Show a WATCH and ask the respondent } \\
\text { to say the name }\end{array}$ & 20.23 & 21.91 & 0.84 \\
\hline $\begin{array}{l}\text { Show a PEN and ask the respondent to } \\
\text { say the name }\end{array}$ & 20.24 & 21.75 & 0.84 \\
\hline $\begin{array}{l}\text { Repeat the phrase:"NOT HERE, NOT } \\
\text { THERE" }\end{array}$ & 20.41 & 20.56 & 0.84 \\
\hline Take the sheet with the right hand & 20.31 & 21.41 & 0.84 \\
\hline Correctly fold the sheet & 20.27 & 21.31 & 0.84 \\
\hline Put the leaf on the floor & 20.30 & 20.73 & 0.84 \\
\hline $\begin{array}{l}\text { Do what is written in the sentence: } \\
\text { close your eyes }\end{array}$ & 20.65 & 19.56 & 0.83 \\
\hline Make a sentence & 20.81 & 19.82 & 0.84 \\
\hline Make the same drawing & 20.79 & 19.67 & 0.83 \\
\hline Total score & & & 0.84 \\
\hline
\end{tabular}

Table 4 - Quality of life facets distribution of the studied elderly, Recife, Pernambuco, Brazil, 2016-2017

\begin{tabular}{lccccc}
\hline Facets & Mean & $\begin{array}{c}\text { Standard } \\
\text { Deviation }\end{array}$ & Amplitude & Minimum & Maximum \\
\hline Total score & 85.29 & 13.04 & 62 & 52 & 114 \\
SF & 9.10 & 2.75 & 13 & 4 & 17 \\
AUT & 13.09 & 2.97 & 14 & 6 & 20 \\
PPF & 14.02 & 3.06 & 15 & 5 & 20 \\
SOP & 14.25 & 3.08 & 14 & 6 & 20 \\
DAD & 9.36 & 4.20 & 16 & 4 & 20 \\
INT & 13.48 & 4.02 & 16 & 4 & 20 \\
\hline
\end{tabular}

Note: WHOQOL: World Health Organization Quality of Life; SF = Sensory Functioning; $A U T=$ Autonomy; $P P F=$ Past, Present and Future Activities; $S O P=$ Social Participation; $D A D=$ Death and Dying; INT = Intimacy.

The area under the Receiver Operating Characteristics (ROC) curve for the Logistic Regression Model was 0.68 (Cl 0.59-0.76; $\mathrm{p}<0.001$ ) for cognitive impairment (Figure 1).

A reliability test of MMSE items was performed. The scale mean without item, the scale variable without item and the Cronbach's alpha (a) were analyzed, with a total score of 0.84 (Table 03).
Regarding the WHOQOL-OLD, the domain sensory functioning, which assesses cognitive functioning and sensory skills, had the lowest score, while the social participation domain, which assesses participation in community activities, the elderly obtained the highest score (Table 4).

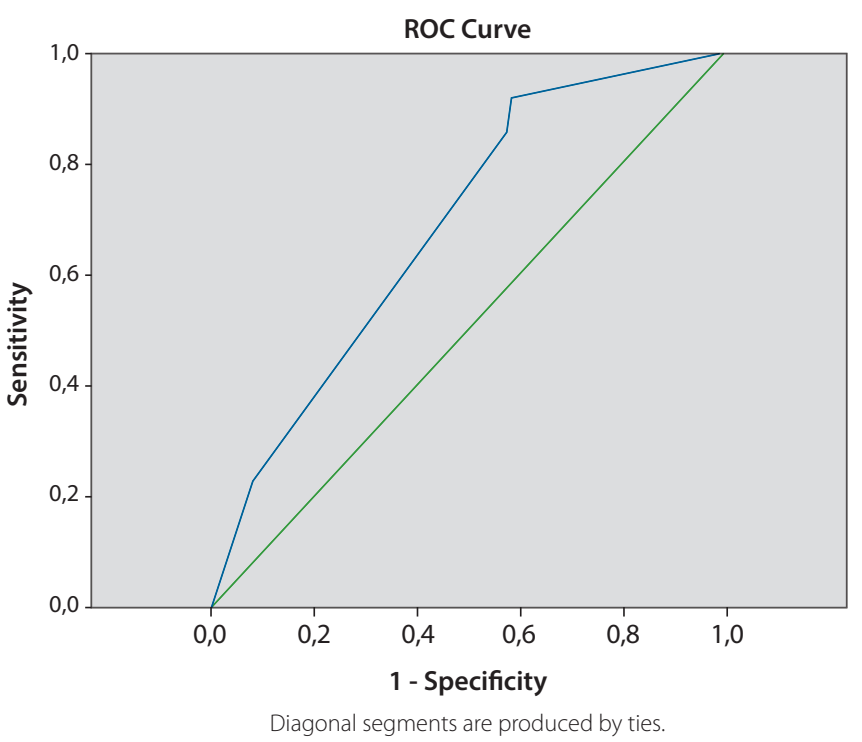

Figure 1 - Receiver Operating Characteristics curve, based on the Logistic Regression Model for cognitive impairment among community-dwelling elderly, Recife, Pernambuco, Brazil, 2016-2017

\section{DISCUSSION}

With regard to sociodemographic data, there was a predominance of females, which may be the result of greater demand for health care compared to men. Overall, men are more resistant to seeking health services associated with feelings of fragility and dependence ${ }^{(22)}$. Male morbidity and mortality is higher due to high mortality rates from external or violent causes (homicides, traffic accidents, suicides and drowning) ${ }^{(23)}$, characterizing the feminization of aging. Regarding the age group, most of the elderly were aged 60-70 years. This number is close to the official estimates of life expectancy in the country, which is 75.5 years ${ }^{(24-25)}$.

In relation to education, most participants had low education. Opportunities for entry to school institutions were low in the twentieth century ${ }^{(26)}$, which demonstrates this low level of education, and access was more difficult, especially for women and low-income people ${ }^{(21,27)}$.

There was a predominance of elderly people who received up to 1 minimum wage, corroborating the literature ${ }^{(5,8,18,22)}$. The low socioeconomic status among the elderly can limit the living conditions of these individuals, leading to negative consequences such as withdrawal from social life, which can worsen as they remain contributing significantly to the family budget ${ }^{(18,22)}$.

Regarding cognitive assessment, it was found that the attention/ calculation domain obtained the lowest score. In this case, the level of education may directly intervene in this skill. This is even one of the most commonly seen cognitive deficits in the course of aging. However, the orientation domain reached the highest score. In this situation, studies show that this score is usually low because it is a 
little used skill, since the elderly did not remember dates because they did not have the habit of looking at the calendar, but in the case of this study, there is the positive highlight, because it is observed this domain maintenance. This can be explained by the greater independence of these elderly in performing their activities, thus maintaining this functioning domain ${ }^{(24,28)}$.

No association was found between gender and MMSE participant performance. Information about this association portrayed in the literature is conflicting, as women are more exposed to social vulnerability throughout their lives and there are no studies demonstrating the impact of aging on different genders. The difference between gender and cognition can be, among other reasons, highlighted by schooling, as well as opportunities and encouragement experienced differently during life by elderly women and men ${ }^{(11,29)}$.

There was also no significant association between MMSE performance and age, differing from national and international studies. This can be explained because, in this study, the number of young elderly is predominant, which differs from a large part of other research. Moreover, chronological age separately does not satisfactorily justify cognitive aging ${ }^{(27,29-30)}$.

With regard to education, older people who have more years of age usually have better results in cognitive assessment, however, in contrast to other studies, education did not influence the performance of the elderly in $\mathrm{MMSE}^{(30-31)}$.

However, what is reaffirmed in this research is that, most of the elderly presented cognitive deficit, even with a predominance of literate elderly, which may present throughout the aging process and is related to biological losses related to time, beyond the individual's personal experience. The most common types of cognitive deficits found in the elderly are forgetfulness of recent events, difficulty in performing calculations, changes in the state of attention, decreased reasoning and concentration, and slower motor activities with decreased fine motor skills. These deficits may modify the routine of the elderly, leading to dependence ${ }^{(24)}$.

As MMSE is a tool for tracking cognitive impairment, identifying the cognition level of the elderly can enable the elaboration of interventions aimed at meeting their demands, improving the quality of life. Since physical performance and social interaction of the elderly are dependent on their cognitive functions, it is essential to maintain appropriate and satisfactory cognition, allowing the subject to understand and solve everyday problems, thus defining them as rational and thinking beings ${ }^{(24)}$. In the meantime, the results of this study were presented to the FHU teams to direct action planning to minimize and/or prevent the damage caused by cognitive decline.

Significant association between marital status and housing arrangement with cognitive impairment points out that elderly widowed/divorced/never married and living alone have a higher cognitive deficit. Moreover, this data was reinforced in the regression model since the elderly without a partner have a 3.87 times chance of developing this cognitive decline. This result can be justified by the company of someone setting up as a support organization for this elderly and, consequently, preventing/ minimizing the occurrence of cognitive changes ${ }^{(32-33)}$. The loss of a loved one coupled with the contempt of the family is a factor that brings with it disastrous consequences for the elderly, causing progressive losses that lead to a decrease in the quality of life of this individual| ${ }^{(33-34)}$.

Regarding analysis between MMSE and WHOQOL-OLD, it was found that there is a significant association, since the low quality of life has 3.41 times the chance of exhibiting cognitive decline. This data converges with the literature since cognitive functions have relevant practical implications and direct impacts on the elderly's quality of life ${ }^{(35)}$.

Cognitive decline causes impairments in the functional capacity of the elderly in their daily lives, resulting in decreased independence and autonomy, which varies according to the degree of severity and causes a decrease in the individual's quality of life ${ }^{(36)}$.

In this study, most of the elderly had good quality of life indices. However, the sensory functioning facet showed the lowest score. Since aging is characterized by a process of continuous changes and physiological declines, sensory impairment reflects significant damage to the elderly, especially in daily life activities, autonomy, safety, personal interactions and, consequently, poor performance in quality of life ${ }^{(35)}$.

Social participation of the elderly in the community positively reflects on the quality of life and constitutes a determinant in active aging. The inclusion of these individuals in group activities reduces social isolation, favors the improvement of self-esteem and the development of positive behaviors associated with selfcare and health promotion. In view of this, the social participation facet obtained the highest score, corroborating the Ministry of Health recommendations and diverging from national studies that assessed this facet with the result inferior to the others ${ }^{(16,35,37-38)}$.

Given this, the assessment of cognitive deficit during care for the elderly is essential since it has important predisposing factors, requiring prevention and early detection goals to be established in order to provide a higher quality of life at the individual and collective levels for this public.

\section{Study limitations}

A cross-sectional design of this research limits the implications of the study by not allowing a causality or longitudinality assessment. Only comparisons and associations can be made, raising likely risk factors.

\section{Contributions to Nursing, Health or Public Policies}

Data from this study contribute to the improvement of nursing care for the elderly, since it becomes evident the need for attention to the assessment of cognitive functions among the elderly community. Moreover, the results presented here denote the importance of the initial diagnosis of cognitive impairment, aiming at an operative treatment and making possible the development of skillful measures to promote quality of life during aging.

\section{CONCLUSION}

The data analyzed allow us to conclude that most participants were female with active age, income up to 1 minimum wage constituted by retirement. Cognitive function of these elderly individuals had a low score, especially in the attention/calculus category. However, the quality of life of most elderly individuals 
was classified as medium or high according to the WHOQOL total score, despite the low index in the sensory functioning facet.

According to these results, it is emphasized the need for multidimensional evaluation of the elderly in Primary Health Care actions, especially the sensory and cognitive functions. The nurse will be able to guide nursing care and interventions, including MMSE application and tests to assess visual and hearing acuity, which allow early identification of health problems that condition functional decline in the elderly, preventing disabilities and promoting active aging in this population.

\section{REFERENCES}

1. Silva AR, Sgnaolin V, Nogueira EL, Loureiro F, Engroff $P$, Gomes I. Doenças crônicas não transmissíveis e fatores sociodemográficos associados a sintomas de depressão em idosos. J Bras Psiquiatr. 2017;66(1):45-51. doi: 10.1590/0047-2085000000149

2. You Y, Wang J, Teng W, Ma G, Liu P. Blood pressure and noncommunicable diseases in middle-aged and older adults in China. PLoS One. 2018;13(11):e0206635. doi: 10.1371/journal.pone.0206635

3. Silzer T, Barber R, Sun J, Pathak G, Johnson L, O'Bryant S, et al. Circulating mitochondrial DNA: New indices of type 2 diabetes-related cognitive impairment in Mexican Americans. PLoS One. 2019;14(3):e0213527. doi: 10.1371/journal.pone.0213527

4. Instituto Brasileiro de Geografia e Estatistica (IBGE). Síntese de Indicadores Sociais (SIS): uma análise das condições de vida da população brasileira: 2016 [Internet]. Rio de Janeiro: IBGE;2016 [cited 2018 Sept 03]. Available from: https://www.ibge.gov.br/estatisticas-novoportal/ sociais/trabalho/9221-sintese-de-indicadores-sociais.html?=\&t=o-que-e

5. Silveira MM, Portuguez MW. Analysis of life quality and prevalence of cognitive impairment, anxiety, and depressive symptoms in older adults. Estud Psicol. 2017;34(2):261-8. doi: 10.1590/1982-02752017000200007

6. Silva JA, Souza LE, Ganassoli C. Quality of life in the elderly: prevalence of intervening factors. Rev Soc Bras Clín Méd [Internet]. 2017 [cited 2018 Sep 05];15(3):146-9. Available from: http://docs.bvsalud.org/biblioref/2017/11/875192/sbcm_153_146-149.pdf

7. Oliveira BC, Barbosa NM, Lima MSM, Guerra HS, Neves CM, Avelar JB. Quality of life assessment in elderly from the community. Rev Bras Promoç Saúde. 2017;30(3):1-10. doi: 10.5020/18061230.2017.5879

8. Rinaldi J, Souza GC, Camozzato AL, Chaves MLF. Sixteen-year predictors of successful aging from a Southern Brazilian cohort The PALA study. Dement Neuropsychol. 2018;12(3):228-34. doi: 10.1590/1980-57642018dn12-030002

9. Antunes MDCP, Moreira, MC. Educação intergeracional e envelhecimento bem sucedido. Rev Bras Ciênc Envel Hum. 2018;15(1):21-32. doi: 10.5335/rbceh.v15i1.6052

10. Carneiro DN, Vilela ABA, Meira SS. Avaliação do déficit cognitivo, mobilidade e atividades da vida diária entre idosos. Rev APS [Internet]. 2016 [cited 2018 Sep 07];19(2):203-9. Available from: https://aps.ufjf.emnuvens.com.br/aps/article/view/2303/967

11. Borges EGS, Vale RGS, Pernambuco CS, Cader SA, Sá SPC, Pinto FM, et al. Effects of dance on the postural balance, cognition and functional autonomy of older adults. Rev Bras Enferm. 2018;71(Suppl 5):2302-9. doi: 10.1590/0034-7167-2017-0253

12. Bernardes FR, Machado CK, Souza MC, Machado MJ, Belaunde AMA. Subjective memory complaints and their relationship with verbal fluency in active older people. CoDAS. 2017;29(3):e20160109. doi: 10.1590/2317-1782/20172016109

13. Lima CMB, Alves HVD, Mograbi DC, Pereira FF, Fernandez JL, Charchat-Fichman H. Performance on cognitive tests, instrumental activities of daily living and depressive symptoms of a community-based sample of elderly adults in Rio de Janeiro, Brazil. Dement Neuropsychol. 2017;11(1):54-61. doi: 10.1590/1980-57642016dn11-010009

14. World Health Organization (WHO). World Aging and Health Report [Internet]. Geneva: WHO; 2015 [cited 2018 Sept 17]. Available from: http://apps.who.int/iris/bitstream/handle/10665/186463/9789240694811_eng.pdf;jsessionid=89FBF0BE89743BB02A46776E2D902F39?seq uence $=1$

15. Alves DSB, Barbosa MTS, Caffarena ER, Silva AS. Caracterização do envelhecimento populacional no município do Rio de Janeiro: contribuições para políticas públicas sustentáveis. Cad Saúde Colet. 2016;24(1):63-9. doi: 10.1590/1414-462X201600010272

16. Santos SC, Tonhom SFR, Komatsu RS. Saúde do idoso: reflexões acerca da integralidade do cuidado. Rev Bras Promoç Saúde [Internet]. 2016 [cited 2018 Dec 04]; 29(Suppl 5):118-27. Available from: http://periodicos.unifor.br/RBPS/article/view/6413/5220

17. Ministério da Saúde (BR). Conselho Nacional de Saúde. Resolução no 510, de 7 de abril de 2016. Diário Oficial, Brasília, 2016 May 24. Brasília: Ministério da Saúde; 2016 [citado 2018 Sep 21]. Available from: http://bvsms.saude.gov.br/bvs/saudelegis/cns/2016/res0510_07_04_2016.html

18. Porciúncula RDCR, Carvalho EF, Barreto KML, Leite VMM. Socio-epidemiological profile and autonomy of elderly in the city of Recife, northeastern Brazil. Rev Bras Geriatr Gerontol. 2014;17(2):315-25. doi: 10.1590/\$1809-98232014000200009

19. Menezes AV, Aguiar AS, Alves EF, Quadros LB, Bezerra PP. Função executiva de idosos institucionalizados e comunitários: relação com capacidades cognitivas e funcionais. Saúde Pesqui 2016;9(3):405-14. doi: 10.17765/2176-9206.2016v9n3p405-414

20. Melo DMD, Barbosa AJG. O uso do Mini-Exame do Estado Mental em pesquisas com idosos no Brasil: uma revisão sistemática. Ciênc Saúde Colet. 2015;20(12):3865-76. doi: 10.1590/1413-812320152012.06032015

21. Rocha RE, Mineiro L, Boscatto EC, Mello MF. Aptidão funcional e qualidade de vida de idosos frequentadores de uma universidade aberta da maior idade. J Phys Educ. 2016;27:e2725. doi: 10.4025/jphyseduc.v27i1.2725 
22. Barbosa LR, Silva TDCS, Santos MF, Carvalho FR, Marques RVDA, Matos Júnior EM. Perfil sociodemográfico e clínico dos idosos de um Centro de Convivência. Rev Kairós-Gerontol. 2018;21(2):357-73. doi: 10.23925/2176-901X.2018v21i2p357-373

23. Carmo ÉA, Souza TS, Nery AA, Vilela ABA, Filho IEM. Trend of mortality from external causes in elderly. Rev Enferm UFPE. 2017;11(Suppl.1):374-82. doi: 10.5205/reuol.7995-69931-4-SM.1101 sup201717

24. Martins JB, Lange C, Lemões MAM, Llano PMP, Santos F, Avila JA. Evaluation of cognitive performance in older adult residents of a rural área. Cogitare Enferm. 2016;21(3):01-09. doi: 10.5380/ce.v21i3.48943

25. Instituto Brasileiro de Geografia e Estatística (IBGE). Tábua de Mortalidade de 2015 [Internet]. Rio de Janeiro: IBGE; 2018 [cited 2018 Nov 03]. Available from: ftp://ftp.ibge.gov.br/Tabuas_Completas_de_Mortalidade/Tabuas_Completas_de_Mortalidade_2015/tabua_de_ mortalidade_analise.pdf

26. Soares MRP, Istoé RSC. Alfabetização e inclusão de pessoas idosas: uma proposta interdisciplinar mediada pelas tecnologias da informação e da comunicação. Rev Cient Interdisc. 2015;2(3):165-75. doi: 10.17115/2358-8411/v2n3a17

27. Melo BRS, Diniz MAA, Casemiro FG, Figueiredo LC, Santos-Orlandi AA, Haas VJ, Orlandi FS, Gratão ACM. Cognitive and functional assessment about elderly people users of health public service. Esc. Anna Nery. 2017;21(4):e20160388. doi: 10.1590/2177-9465-ean-2016-0388

28. Cruz TJP, Sá SPC, Lindolpho MC, Caldas CP. Cognitive stimulation for older people with Alzheimer's disease performed by the caregiver. Rev Bras Enferm. 2015;68(4):450-6. doi: 10.1590/0034-7167.2015680319i

29. Ferreira LS, Pinho MDSP, Pereira MWDM, Ferreira AP. Perfil cognitivo de idosos residentes em Instituições de Longa Permanência de BrasíliaDF. Rev Bras Enferm. 2014;67(2):247-51. doi: 10.5935/0034-7167.20140033

30. Langa KM, Levine DA. The Diagnosis and Management of Mild Cognitive Impairment: A Clinical Review. JAMA. 2014;312(23):2551-61. doi: 10.1001/jama.2014.13806

31. Sposito G, Neri AL, Yassuda MS. Advanced Activities of Daily Living (AADLs) and cognitive performance in community-dwelling elderly persons: Data from the FIBRA Study-UNICAMP. Rev Bras Geriatr Gerontol. 2016;19(1):7-20. doi: 10.1590/1809-9823.2016.15044

32. Miranda ACC, Sérgio SR, Fonseca GNS, Coelho SMC, Rodrigues JS, Cardoso CL, Cassiano JG. Avaliação da presença de cuidador familiar de idosos com déficits cognitivo e funcional residentes em Belo Horizonte-MG. Rev Bras Geriatr Gerontol. 2015;18(1):141-50. doi: 10.1590/1809-9823.2015.13173

33. Grden CRB, Rocha JHL, Cabral LPA, Sousa JAV, Reche PM, Borges PKO. Factors associated with performance in the Mini Mental State Examination: a cross-sectional study. O Braz J Nurs. 2017;16(2):170-8. doi: 10.17665/1676-4285.20175607

34. Cruz DT, Cruz FM, Ribeiro AL, Veiga CL, Leite ICG. Associação entre capacidade cognitiva e ocorrência de quedas em idosos. Cad Saúde Colet. 2015;23(4):386-93. doi: 10.1590/1414-462X201500040139

35. Santos $C A D$, Ribeiro $A Q$, Rosa $C D O B$, Ribeiro RDCL. Depressão, déficit cognitivo e fatores associados à desnutrição em idosos com câncer. Ciênc Saúde Colet. 2015;20(3):751-60. doi: 10.1590/1413-81232015203.06252014

36. Chaves AS, Santos AMD, Alves MTSSB, Salgado Filho N. Association between cognitive decline and the quality of life of hypertensive elderly individuals. Rev Bras Geriatr Gerontol. 2015;18(3):545-56. doi: 10.1590/1809-9823.2015.14043

37. Paula GR, Souza BN, Santos LF, Barbosa MA, Brasil VV, Oliveira LMAC. Quality of life assessment for health promotion groups. Rev Bras Enferm [Internet]. 2016;69(2):222-9. doi: 10.1590/0034-7167.2016690206i

38. Rodrigues LR, Tavares DS, Dias FA, Pegorari MS, Marchiori GF, Tavares DMS. Quality of life of elderly people of the community and associated factors. Rev Enferm UFPE. 2017;11(Suppl 3):1430-8. doi: 10.5205/reuol.10263-91568-1-RV.1103sup201715 